\title{
m46.p02
}

\section{Synthesis and crystal structure of a new rhenium scandium oxide, $\mathrm{Sc}_{6} \mathrm{ReO}_{12}$}

\section{Mikhailova, H. Ehrenberg, H. Fuess}

Institute for Materials Science, Darmstadt University for Technology, Petersenstr.23,D-64287, Darmstadt, Germany.E-mail:mikhailova@st.tudarmstadt.de

\section{Keywords: $\mathrm{Sc}_{6} \operatorname{ReO}_{12}$, distorted fluorite structure, magnetism of $\operatorname{Re}^{+6}$}

A number of $\mathrm{Ln}_{6} \mathrm{MO}_{12}$ phases, where $\mathrm{Ln}=$ rare earth cation and $\mathrm{M}=\mathrm{Mo}, \mathrm{W}, \mathrm{Re}$ or $\mathrm{U}$, crystallizes in a distorted rhombohedral fluorite structure with space group R-3 [1,2]. The same crystal structure is observed for $\mathrm{Sc}_{6} \mathrm{MO}_{12}$ compounds, where $\mathrm{M}=\mathrm{Mo}$ and $\mathrm{W}[3]$. In our work a new complex rhenium scandium oxide, $\mathrm{Sc}_{6} \mathrm{ReO}_{12}$, has been synthesized as a single phase in a sealed silica tube and by high-pressure high-temperature synthesis, and its crystal structure has been determined by single crystal X-ray diffraction. This compound crystallizes in a rhombohedral structure (space group R-3, a = 9.248(2) $\AA$, $c=8.720(2) \AA, Z=3$ ). Figure 1 demonstrates the dependence of the cell parameters "a" and "c" on the ionic radius of the trivalent cations in the isostructural compounds $\mathrm{Ln}_{6} \mathrm{ReO}_{12}(\mathrm{Ln}=\mathrm{Sc}, \mathrm{Ho}, \mathrm{Er}, \mathrm{Tm}, \mathrm{Yb}$ and $\mathrm{Lu})$. This structure represents a three-dimensional framework formed by $\mathrm{ReO}_{6}$ and $\mathrm{ScO}_{7}$ polyhedra connected via edges and corners. $\mathrm{ReO}_{6}$ octahedra are undistorted, the Re-O interatomic distance $\mathrm{d}_{\mathrm{Re}-\mathrm{O}}=1.926 \AA$ is in a good agreement with the Re-O distances observed for other Re containing oxides with a formal rhenium oxidation state $+6 . \mathrm{ScO}_{7}$ polyhedra represent capped prisms with six close oxygens $\left(\mathrm{d}_{\mathrm{Sc}-\mathrm{O}}=2.027-2.230 \AA\right.$, in agreement with average $\mathrm{Sc}-\mathrm{O}$ distances in other Sc-containing oxides), and one more distant oxygen $\left(\mathrm{d}_{\mathrm{Sc}-\mathrm{O}}=2.67 \AA\right)$, which is included in the coordination sphere due to calculated bond-valence parameters. The synthesis of $\mathrm{Sc}_{6} \mathrm{ReO}_{12}$ under high pressure indicates the stability of its structure up to $50 \mathrm{kbar}$ and 1300 ${ }^{\circ} \mathrm{C}$. The magnetic properies of $\mathrm{Sc}_{6} \mathrm{ReO}_{12}$ were also investigated.

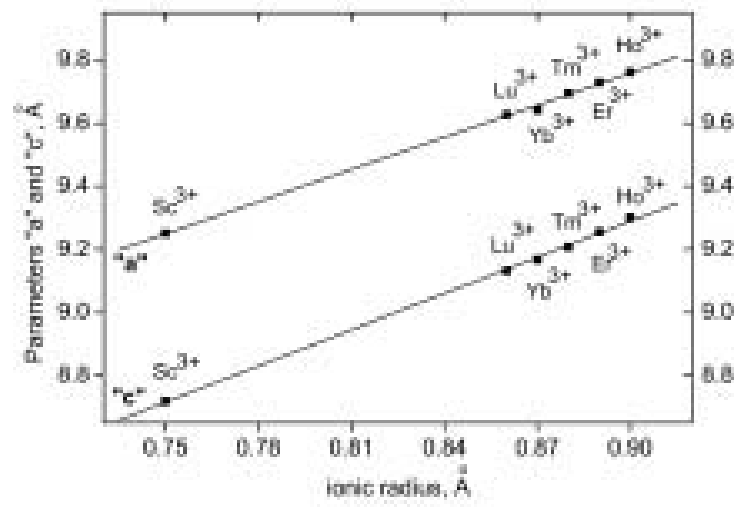

Figure1. "a" and "c" cell parameters dependence on the ionic radius for $\mathrm{Ln}_{6} \mathrm{ReO}_{12}(\mathrm{Ln}=\mathrm{Ho}, \mathrm{Er}, \mathrm{Tm}, \mathrm{Yb}, \mathrm{Lu})$ and $\mathrm{Sc}_{6} \operatorname{ReO} \mathrm{O}_{12}$.

[1] E. A. Aitken, S. F. Bartram, E. F. Juenke, Inorg. Chem. 3 (1964) 949-954.

[2] T. Hartmann, H. Ehrenberg, G. Miehe, G. Wltschek, H. Fuess, J. Solid State Chem. 148 (1999) 220-223.

[3] L. N. Komissarova. Inorganic and analytical chemistry of scandium. Moscow, 2001, Editorial URSS, 510 p. (in Russ.). 